Article

\title{
Leisure-Time Physical Activity in Relation to the Stages of Changes and Achievement Goals in Adolescents: Comparative Study of Students in Spain, Costa Rica, and Mexico
}

\author{
Raúl Baños ${ }^{1}$ (D) , Francisco Ruiz-Juan ${ }^{2, *}$, Antonio Baena-Extremera ${ }^{3}$, \\ María Elena García-Montes ${ }^{2}$ and María del Mar Ortiz-Camacho ${ }^{3}$ \\ 1 Faculty of Sports Sciences, Autonomous University of Baja California, Ensenada 22890, Mexico; \\ raulfb89@gmail.com \\ 2 Department of Physical Activity and Sport, University of Murcia, 30720 San Javier, Spain; garciamo@um.es \\ 3 Department of Didactics of Musical, Plastic and Corporal Expression, University of Granada, \\ 18071 Granada, Spain; abaenaextrem@ugr.es (A.B.-E.); mmortiz@ugr.es (M.d.M.O.-C.) \\ * Correspondence: pacoruizjuan@gmail.com; Tel.: +34-868-88-85-00
}

Received: 6 June 2018; Accepted: 20 July 2018; Published: 23 July 2018

\begin{abstract}
The aim of this study was to analyze the relationship between levels of leisure-time sports and physical activity and the stages of change in high school students with goal orientations. Methods: The sample was conformed of 2168 students randomly selected to participate in a longitudinal study in Costa Rica (423), Mexico (408), and Spain (1337), with 1052 being boys, 1037 girls, and 79 who did not specify sex, aged between 11 and 16 years old $(M=12.49, S D=0.81)$. We used a questionnaire to ask students about their leisure-time sports and physical activity, about stages of change and to measure achievement goals. Results: The results show that students are more active in Costa Rica, most of them being in a stage of active change. Conclusions: We found significant differences in achievement goals in all three countries, which shows that students in active stages have higher values than those in the inactive stage.
\end{abstract}

Keywords: physical education; goals orientations; stage of change

\section{Introduction}

Physical education students develop a series of psychological characteristics throughout their school years, for example the perception of motivational climates (the psychological atmosphere in which they are training), their stage of change or the motivation, which can strongly affect their academic and personal environment [1]. Motivation is defined by psychologists as the process by which activities are started, directed, and sustained so that certain needs are met, either psychological or physical. Therefore, physical education teachers should be aware of the most suitable conditions for their students' learning and how to attain them, as the positive effect of teachers with such information on their students would be beneficial.

During adolescence, students can have different goal orientations (in the knowledge that some of them are more suitable for learning) and place themselves in a stage of change which negatively affects physical education practice. Méndez-Giménez et al. [2], for example, shows that girls are situated on a mastery goals profile (avoidance-approach) with high rates of physical activity whereas boys are situated in a moderately high performance goals profile [3] and low mastery goals with less physical activity. However, according to Granero-Gallegos et al. [4], boys tend to show higher levels of physical education practice than girls. 
A large number of studies have shown that certain characteristics in students are better than others when it comes to achieving positive effects in education. Méndez-Giménez et al. and Wang et al. [2,5], for instance, analyzed goal achievement profiles and found that the "high achievement goals" profile was the most positive feature pattern, with high self-determined motivation, competence perception, and relationship with the others, fun, effort, and physical education practice and low levels of boredom and motivation which means a state of lacking any intention to engage in a behavior and is a completely non self-determined form of regulation. Something similar happened in the case of the "mastery achievement goals" group. Standage et al. [6], for their part, have shown evidence of an important link between the mastery goal orientation and self-determined motivation; subjects who involve themselves in activities and freely commit to them for pleasure, fun, and joy, are classed as being in this state $[7,8]$. In this same line, Standage et al. [6] found poor connection between performance oriented goals and self-determination.

The Achievement Goals Theory studies the different dispositional and environmental factors affecting achievement motivation. According to this theoretical construct there are two types of dispositional goals orientations. One is task orientation, which manifests itself when the goal is related to learning and students assess their capacity level by a process of comparing to themselves. The other is ego orientation, in which the goal is characterized by competition and students assess their level by comparing themselves with the other students $[9,10]$. Task oriented students see education as a goal in itself, perceive practice as an activity which reinforces the capacity to cooperate and increases their interest in learning, whereas ego oriented students see education as a mean to obtain validation and social status $[8,10]$. Thus, task orientation is associated with greater levels of positive motivation, affective, and behavioral patterns than ego orientation [6].

Based on this proposition, other researchers [11,12] have proposed improvements to this model, such as the mastery (task), performance (ego), introducing the concept of approach, (positive orientation to the achievement of an objective), and avoidance (negative orientation to the achievement of an objective); therefore the concept of approach makes a reference that the subject shows its ability and competence and the concept of avoidance makes a reference that the subject tries not to show its incompetence [13].

Based on this idea, a series of researchers, among them Elliot [12], developed the $2 \times 2$ model. This model includes four possible goals divided into the two aforementioned perspectives: mastery-approach (absolute and intrapersonal definition of competition and positive value), performance-approach (normative definition and negative value), and performance-avoidance (normative definition and negative value).

The fact that students can find themselves with one of the aforementioned goals can be also related to, or affected by, the potential stages of change (Marcus and Forsyth, 2003) [14] teenagers might go through during their school years. The stages of change represent a time dimension which allow us to understand when changes in behavior take place (Marcus and Forsyth, 2003; Prochaska et al., 1992) $[14,15]$. The stages of change are called precontemplation, contemplation, determination, action, and maintenance (Prochaska et al., 1992) [15]. These stages are important as each one of them involves the students' adoption of a pattern of attitudes and behaviors which can affect their way of dealing with school, friends, and even the practice of physical education. It is of great importance in physical education teaching to be aware of our students' current stage of change and their goal orientation in order to plan teachers' educational processes and promote the sports habits and practices as required at the curricular level. In this way, another school factor which can have an effect on our students is leisure-time physical activity. One of the major objectives of the physical education subject is for students to acquire healthy and long-lasting sports and physical activity habits. This is a highly important aspect which has given rise to numerous studies analyzing the benefits of these leisure-time habits on students (Ardoy et al., 2010; Nuviala et al., 2011) [16,17]. But this research intends to go further as it attempts to analyze not only whether students have these habits, but how these habits can be associated with certain stages of change and even more important, with certain goal orientations and the effects that each of them can have on students. 
In view of all this, the object of this study is to find out the relationship between levels of leisure-time sports and physical activity and the stages of change in high school students and goal orientations across three countries, so as to assess if each tendency is general in all of them or otherwise.

\section{Materials and Methods}

\subsection{Participants}

The sample was of 2168 students in their first year of high school. The students are from three countries, 423 from Costa Rica, 408 from Mexico and 1337 from Spain. Exactly 1052 were male students (50.4\%) and 1037 female students (49.6\%), 79 students did not specify gender. $86.6 \%$ were students of public schools while only $13.4 \%$ belong to private schools. The age range was 11 to 16 years old $(M=12.49 ; S D=0.81)$, the average age was 12.53 for boys $(S D=0.87)$ and 12.44 for girls $(S D=0.74)$. The study started from February 2011 to June 2016.

\subsection{Procedure}

We asked schools for permission to carry out the research in a letter explaining the aims of the study and how it would be carried out; a model of the instrument that would be used was attached. This instrument was self-administered, and it was applied on a large scale; it was filled in anonymously during a school day, with prior agreement and training given by the evaluators. Subjects were debriefed on the object of the study, its voluntary nature and on the absolute confidentiality for the answers and data management; it was explained there were no correct or incorrect answers and they were asked to reply with maximum sincerity and honesty. Only students whose parents and guardians had given informed consent participated in the study. To do this research, it was necessary that an ethical committee of the University of Murcia give permission.

\subsection{Instruments}

Leisure-time sport and physical activity. This was measured following the same procedure as Piéron et al. and Ruiz-Juan et al. [18,19]. One question was used in order to determine whether respondents did or did not do leisure-time sport and physical activities defined in the following way: "We understand sports and physical activities are those which are carried out with an intention of partaking in physical exercise and which are practiced with some regularity. They include regulated forms such as football, basketball, athletics, tennis, swimming ..., others more open in nature such as mountaineering, cycle-touring, climbing, scuba diving ... and those each person practices according to their own tastes, such as running, swimming, biking ... " Students were asked to report whether (a) they had partaken in sports-physical activity in the 2010-2011 school year; (b) they had not partaken in sports-physical activity in the 2010-2011 school year but they had done so in previous years or (c) they had never done sports-physical activity. The respondents who selected the latter two options were classified as "sedentary". Those who stated they partook in sports-physical activity answered five additional questions which allowed us to calculate the rate or quantity pattern of habitual sports and physical activity (Finnish index of sports and physical activity) and refer to frequency, duration, intensity, and participation in organized sports and sports competitions [20]. The answers were recorded in three categories so that they all had similar weight and we calculated the index or pattern. The resulting value oscillated between 5 and 15. The lowest results are typical of the less active people, while the highest scores correspond to the most active subjects. This measure was used in 2008 and 2010 with adolescents $[18,19]$ in previous research and in order to better represent physical activity patterns, the scoring was used to classify participants into vigorous, moderate, mild, and insufficient activity categories. For analytical purposes we created a dichotomous variable by means of grouping participants classified as vigorously active and moderately active (high level of sports-physical activity) at one end and those mildly and insufficiently active (low level of sports-physical activity) at the 
other end. Cronbach's alpha revealed high reliability for this set of variables $(\alpha=0.88$ Costa Rica, $\alpha=0.83$ México, and $\alpha=0.87$ Spain) and was similar to that obtained in the above cited studies.

Stages of change Questionnaire [15,21]. In line with previous studies [22-24] subjects placed themselves in one of these five stages of change: precontemplation, contemplation, determination, action, and maintenance (Table 1). Exactly, this instrument begin with the next sentence: "physical activity or exercise includes activities such as brisk walks, running, cycling, swimming, or any other activity which involves at least the same intensity as these activities". Students were asked to choose YES or NO regarding the following statements: (1) I am physically active at the moment; (2) I have an intention to be more physically active within the next 6 months. Those who selected YES in question (1) did not answer question (2) and moved on to questions (3) and (4). Regular activity was previously defined in the following way: "For activity to be regarded as regular it has to add up to a total of $30 \mathrm{~min}$ or more at least 5 days a week. For example, you could take a 30 min walk or take 310 -min walks a day to reach a daily total of $30 \mathrm{~min}$ ". Students were asked to choose YES or NO for the following statements (3) I partake in regular physical activity at the moment; (4) I have been partaking in regular physical activity over the last 6 months. For analytical purposes we created a dichotomous variable by grouping the students classified under the active stages (action and maintenance) at one end, and under the inactive stages (precontemplation, contemplation, and determination) at the other end.

Table 1. Categorization of subjects in stages of change.

\begin{tabular}{ccccc}
\hline $\mathbf{( 1 )}$ & $\mathbf{( 2 )}$ & $\mathbf{( 3 )}$ & $\mathbf{( 4 )}$ & Stage \\
\hline No & No & - & - & Precontemplation \\
No & Yes & - & - & Contemplation \\
Yes & - & No & - & Determination \\
Yes & - & Yes & No & Action \\
Yes & - & Yes & Yes & Maintenance \\
\hline
\end{tabular}

$2 \times 2$ Achievement Goals adapted to physical education by Moreno et al. [25], Spanish version by Wang et al. [3], created to measure achievement goal orientations in physical education students. The original instrument includes 12 items and four subscales (three items per factor): mastery-approach, mastery-avoidance, performance-approach, and performance-avoidance. The header read: "In my physical education class ... " The answers were collected on a Likert scale from 1 (totally disagree) to 7 (totally agree).

\subsection{Psychometric Properties of $2 \times 2$ Achievement Goals}

Psychometric properties were estimated following the analysis procedure set up by Carretero-Dios and Pérez [26]. None of the items were eliminated post-analysis as they all satisfied the established requirements, $(\geq 0.30$ value in item-total corrected correlation coefficient, $>1$ standard deviation; all the answer options were used). The homogeneity analysis showed no item overlapping across theoretical dimensions on both questionnaires. The asymmetry and kurtosis indices were close to zero and $<2.0$ as recommended by Bollen and Long [27], which indicates similarity to the univariate standard curve. The factor validity of the four instruments was analyzed with CFA. Bootstrapping was used, as well as the maximum likelihood procedure, an estimation of structural equation models which assumes normal univariate distribution, and a continuous scale given that the bulk of the data lack multivariate standardization, which violates one of the basic rules of CFA.

The model's fit to the data was assessed by means of combining absolute and relative fit indices. The four scales show correct values which allow for the establishing an acceptable fit to the original model [28] as seen in the results obtained (Table 2). The standardized relation coefficients of the latent variable with each of the items ranged between 0.75 and 0.93 ; standardized factor loads were $>60$ in all cases and the $t$-value was always $>1.96$, which guarantees convergent validity of all the instruments used in this study [29]. 
Table 2. Fit indices for the $2 \times 2$ Achievement Goals Model.

\begin{tabular}{lcccccc}
\hline & $\chi^{2} / g l$ & TLI & IFI & CFI & RMSEA & SRMR \\
\hline Costa Rica $(n=360)$ & 2.88 & 0.97 & 0.98 & 0.98 & 0.06 & 0.02 \\
México $(n=389)$ & 4.22 & 0.92 & 0.94 & 0.94 & 0.08 & 0.04 \\
Spain $(n=1062)$ & 4.07 & 0.96 & 0.97 & 0.97 & 0.07 & 0.03 \\
Desirable & $<5$ & $>0.9$ & $>0.9$ & $>0.9$ & $<0.08$ & $<0.05$ \\
\hline
\end{tabular}

\subsection{Data Analysis}

Item and homogeneity analyses, subscale correlations (Pearson coefficient), internal consistency (Cronbach's alpha), Chi Square test $\left(\chi^{2}\right)$, Student's $t$-test, ANOVA, and MANOVA were carried out with SPSS 17.0. The factor structure was assessed with AMOS 21.0 confirmatory factor analysis (CFA).

\section{Results}

\subsection{Descriptive Statistics and Correlation Analysis}

The results of behaviors vis-à-vis leisure-time sports and physical activity (Table 3) show clear significant differences $(p<0.001)$ across all three countries. Thus, the highest percentages of active students are in Costa Rica (88.5\%), whereas only $34.8 \%$ of students are active in Mexico, which causes this country to have the highest dropout rate $(52.0 \%)$ and no practice ever $(13.2 \%)$ percentages. Dropout rates are a problem also in Spain $(22.5 \%)$.

The sports-physical activity pattern reveals a quite worrying picture as only $12.0 \%(10.7 \%+1.3 \%)$ of Mexican students show a high level of sports-physical activity vs. $32.7 \%(29.3 \%+3.4 \%)$ in Spanish students and $23.7 \%(20.7 \%+3.0 \%)$ in Costa Ricans. Thus, what predominates is a low level of sports-physical activity across all three countries (Table 3), especially in Costa Rica where $64.6 \%$ $(44.2 \%+20.4 \%)$ of students have a low level of sports-physical activity.

In terms of stages of change, differences are also statistically significant $(p<0.001)$ across the three countries. $71.9 \%(59.6 \%+12.3 \%)$ of Costa Rican students are in the active stages of change vs. only $32.9 \%(21.9 \%+11.0 \%)$ of Mexicans and $60.8 \%(37.0 \%+23.85 \%)$ of Spaniards. Therefore, slightly more than two-thirds of Mexican students are in inactive stages of change (Table 3).

Table 3. Chi square test $\left(\chi^{2}\right)$ of behaviors, sports-physical activity pattern, and stages of change by country.

\begin{tabular}{|c|c|c|c|c|c|c|c|}
\hline & $n$ & Costa Rica & Mexico & Spain & Total & $x^{2}$ & $p$ \\
\hline \multicolumn{8}{|c|}{ Behavior in relation to leisure-time sports and physical activity } \\
\hline Never & 102 & 1.1 & 13.2 & 4.1 & 5.4 & \multirow{3}{*}{291.20} & \multirow{3}{*}{0.000} \\
\hline Abandoned & 495 & 10.4 & 52.0 & 22.5 & 26.4 & & \\
\hline Active & 1281 & 88.5 & 34.8 & 73.3 & 68.2 & & \\
\hline \multicolumn{8}{|c|}{ Leisure-time sports and physical activity pattern } \\
\hline Sedentary & 597 & 11.6 & 65.2 & 26.7 & 31.9 & \multirow{5}{*}{347.06} & \multirow{5}{*}{0.000} \\
\hline Insufficient & 171 & 20.4 & 4.3 & 7.2 & 9.1 & & \\
\hline Light & 605 & 44.2 & 18.5 & 33.4 & 32.3 & & \\
\hline Mild & 444 & 20.7 & 10.7 & 29.3 & 23.7 & & \\
\hline Vigorous & 54 & 3.0 & 1.3 & 3.4 & 2.9 & & \\
\hline \multicolumn{8}{|c|}{ Stages of change } \\
\hline Precontemplation & 68 & 1.5 & 3.1 & 4.7 & 3.8 & \multirow{5}{*}{358.97} & \multirow{5}{*}{0.000} \\
\hline Contemplation & 510 & 10.2 & 62.0 & 21.7 & 28.4 & & \\
\hline Determination & 199 & 16.4 & 2.0 & 12.8 & 11.1 & & \\
\hline Action & 340 & 12.3 & 11.0 & 23.8 & 18.9 & & \\
\hline Maintenance & 679 & 59.6 & 21.9 & 37.0 & 37.8 & & \\
\hline
\end{tabular}


Table 4 shows statistically significant differences $(p<0.001)$ across the medians of each of the $2 \times 2$ achievement goals variables analyzed by country. The highest scores are in mastery-approach $(M=5.88, D T=1.21$, Mexico $)$ and the lowest ones are in performance-approach $(M=4.14, D T=1.73$, Spain) in all three countries. Likewise, Mexican students obtain the highest scores in all four sub-scales, followed by Costa Ricans and Spaniards. The results of the Bonferroni homogenous subsets show that even though median differences across variables are small, three different subsets can be defined for each of the four variables corresponding to each country.

Table 4. ANOVA of the $2 \times 2$ goal orientation dimensions by country.

\begin{tabular}{|c|c|c|c|c|c|c|c|c|c|c|c|}
\hline & \multicolumn{3}{|c|}{ Costa Rica $(n=360)$} & \multicolumn{3}{|c|}{ México $(n=389)$} & \multicolumn{3}{|c|}{ Spain $(n=1062)$} & \multirow{2}{*}{$F$} & \multirow{2}{*}{ Sig. } \\
\hline & $\alpha$ & $\mathbf{M}$ & DT & $\alpha$ & $\mathbf{M}$ & DT & $\alpha$ & $\mathbf{M}$ & DT & & \\
\hline Performance-approach & 0.91 & 4.66 & 1.80 & 0.88 & 5.11 & 1.66 & 0.88 & 4.14 & 1.73 & 47.99 & 0.000 \\
\hline Mastery-approach & 0.76 & 5.31 & 1.50 & 0.80 & 5.88 & 1.21 & 0.79 & 5.43 & 1.39 & 19.46 & 0.000 \\
\hline Performance-avoidance & 0.81 & 4.91 & 1.58 & 0.72 & 5.31 & 1.37 & 0.71 & 4.59 & 1.53 & 33.76 & 0.000 \\
\hline Mastery-avoidance & 0.84 & 4.92 & 1.52 & 0.76 & 5.17 & 1.39 & 0.81 & 4.68 & 1.43 & 17.33 & 0.000 \\
\hline
\end{tabular}

In terms of factor correlation in $2 \times 2$ goals in physical education, all factors correlated in a positive and significant way in all three countries (Table 5).

Table 5. Correlations between $2 \times 2$ goal orientation factors. Differences across countries.

\begin{tabular}{|c|c|c|c|c|c|c|c|c|c|c|c|c|}
\hline & \multicolumn{4}{|c|}{ Costa Rica $(n=360)$} & \multicolumn{4}{|c|}{ México $(n=389)$} & \multicolumn{4}{|c|}{ Spain $(n=1062)$} \\
\hline & 1 & 2 & 3 & 4 & 1 & 2 & 3 & 4 & 1 & 2 & 3 & 4 \\
\hline 1. Performance-approach & 1 & $0.54^{* *}$ & $0.67^{* *}$ & $0.58 * *$ & 1 & $0.46^{* *}$ & $0.54^{* *}$ & $0.46^{* *}$ & 1 & $0.38^{* *}$ & $0.45^{* *}$ & $0.46^{* *}$ \\
\hline 2. Mastery-approach & & 1 & $0.58 * *$ & $0.60 * *$ & & 1 & $0.50 * *$ & $0.56 * *$ & & 1 & $0.44^{* *}$ & $0.61^{* *}$ \\
\hline 3. Performance-avoidance & & & 1 & $0.57^{* *}$ & & & 1 & $0.59^{* *}$ & & & 1 & $0.53^{* *}$ \\
\hline 4. Mastery-avoidance & & & & 1 & & & & 1 & & & & 1 \\
\hline
\end{tabular}

3.2. Main Relationships and Gender Interaction, Behavior, Sports-Physical Activity Pattern, and Leisure-Time Stages of Change on $2 \times 2$ Goals in Physical Education

We carried out a multivariate analysis (Tables 6 and 7) in which gender, behavior, sports-physical activity pattern and leisure-time stages of change were independent variables and mastery-approach, mastery-avoidance, performance-approach, and performance-avoidance were dependent variables. The MANOVA revealed significant main relationships among dependent and independent variables in all three countries. There were no second-order interaction effects among independent variables $(p>0.05)$ in any of the countries (Table 6).

In terms of gender, there are statistically significant differences in all three countries and in all the variables. Boys always show higher median values than girls (Table 7).

There are statistically significant differences in behaviors in relation to leisure-time sports and physical activity in all three countries and in all the variables. Active subjects always show higher values than sedentary subjects in leisure-time sports and physical activity behaviors (Table 7).

An analysis of the leisure-time sports and physical activity pattern reveals statistically significant differences in all three countries in performance-approach and performance-avoidance. Those who have a high level of sports-physical activity always show higher median values than those with low levels of sports-physical activity (Table 7). In the case of the mastery approach, there are significant differences in Costa Rica $(p=0.001)$ and Spain $(p=0.047)$, and also, higher levels of sports-physical activity have higher median levels than low levels of these activities (Table 7). In Costa Rica this is seen only in mastery-avoidance $(p=0.012)$.

As for mastery-avoidance, there were no statistically significant differences in any of the three countries, and the same happened with the mastery-approach in Costa Rica. In terms of the rest of the variables (performance-approach, mastery-approach, and performance-avoidance) the significant 
differences found in the three countries demonstrate that students in active stages show higher median values than those in inactive stages (Table 7).

Table 6. Univariate and multivariate analyses of $2 \times 2$ goal orientation factors according to gender, behaviors, sports-physical activity pattern, and stages of change.

\begin{tabular}{|c|c|c|c|c|}
\hline \multirow[t]{2}{*}{ (a) } & \multicolumn{4}{|c|}{ Costa Rica } \\
\hline & Gender & Behavior & SFA Pattern & Stages of Change \\
\hline & $F$ & $F$ & $F$ & $F$ \\
\hline Performance-approach & $27.94^{* * *}$ & $6.89^{* *}$ & $4.92 *$ & $3.29 *$ \\
\hline Mastery-approach & $11.26^{* * *}$ & $3.13 *$ & $3.65 *$ & 0.01 \\
\hline Performance-avoidance & $10.96^{* * *}$ & $5.70 *$ & $3.65^{*}$ & $3.01 *$ \\
\hline Mastery-avoidance & $4.28 *$ & $4.59 *$ & $3.32 *$ & 1.33 \\
\hline \multicolumn{5}{|c|}{ Multivariate Analysis } \\
\hline Wilks' Lambda & 0.89 & 0.96 & 0.95 & 0.95 \\
\hline Multivariate F & $7.57^{* * *}$ & $2.58^{*}$ & $2.83 *$ & $2.39 *$ \\
\hline (b) & \multicolumn{4}{|c|}{ Mexico } \\
\hline & Gender & Behavior & SFA Pattern & Stages of Change \\
\hline & $F$ & $F$ & $F$ & $F$ \\
\hline Performance-approach & $23.86^{* * *}$ & $5.83 *$ & $3.12 *$ & $3.56 *$ \\
\hline Mastery-approach & $8.95^{* *}$ & $2.86^{*}$ & 0.06 & $0.09 *$ \\
\hline Performance-avoidance & $8.44^{* *}$ & $5.62 *$ & $3.68 *$ & $3.10 *$ \\
\hline Mastery-avoidance & $3.47 *$ & $2.98 *$ & 0.50 & 0.04 \\
\hline \multicolumn{5}{|c|}{ Multivariate Analysis } \\
\hline Wilks' Lambda & 0.93 & 0.94 & 0.96 & 0.96 \\
\hline Multivariate F & $6.40^{* * *}$ & $5.47^{* *}$ & $4.42 *$ & $4.11 *$ \\
\hline (c) & \multicolumn{4}{|c|}{ Spain } \\
\hline & Gender & Behavior & SFA Pattern & Stages of Change \\
\hline & $F$ & $F$ & $F$ & $F$ \\
\hline Performance-approach & $95.73^{* * *}$ & $3.48 *$ & $4.00 *$ & $4.93 *$ \\
\hline Mastery-approach & $25.44 * * *$ & $5.75 *$ & $2.20 *$ & $3.45 *$ \\
\hline Performance-avoidance & $14.33^{* * *}$ & $4.11 *$ & $3.13^{*}$ & $3.83 *$ \\
\hline Mastery-avoidance & $6.96^{* *}$ & $4.02 *$ & 1.41 & 0.83 \\
\hline \multicolumn{5}{|c|}{ Multivariate Analysis } \\
\hline Wilks' Lambda & 0.88 & 0.95 & 0.95 & 0.97 \\
\hline Multivariate F & $28.08^{* * *}$ & $2.78 *$ & $2.74 *$ & $3.14 *$ \\
\hline
\end{tabular}


Table 7. Medians $(M)$, standard deviation $(S D)$, significance $(F, p$ value), and size of error $(d)$ of $2 \times 2$ Achievement Goals, differences by gender, sports-physical activity behaviors, sports-physical activity patterns, and stages of change.

\begin{tabular}{|c|c|c|c|c|c|c|c|c|c|c|c|c|c|c|c|c|c|c|c|c|c|}
\hline & & \multicolumn{5}{|c|}{ Performance-Approach } & \multicolumn{5}{|c|}{ Mastery-Approach } & \multicolumn{5}{|c|}{ Performance-Avoidance } & \multicolumn{5}{|c|}{ Mastery-Avoidance } \\
\hline & & $M$ & $D T$ & $t$ & $p$ & $d$ & $M$ & $D T$ & $t$ & $p$ & $d$ & $M$ & $D T$ & $t$ & $p$ & $d$ & $M$ & $D T$ & $t$ & $p$ & $d$ \\
\hline & \multicolumn{21}{|c|}{ Gender } \\
\hline Costa Rica & $\begin{array}{l}\text { Chicos }(n=181) \\
\text { Chicas }(n=180)\end{array}$ & $\begin{array}{l}5.14 \\
4.16\end{array}$ & $\begin{array}{l}1.64 \\
1.83\end{array}$ & 5.31 & 0.000 & 0.56 & $\begin{array}{l}5.58 \\
5.04\end{array}$ & $\begin{array}{l}1.35 \\
1.59\end{array}$ & 3.50 & 0.001 & 0.36 & $\begin{array}{l}5.23 \\
4.59\end{array}$ & $\begin{array}{l}1.44 \\
1.65\end{array}$ & 3.88 & 0.000 & 0.41 & $\begin{array}{l}5.10 \\
4.73\end{array}$ & $\begin{array}{l}1.37 \\
1.65\end{array}$ & 2.30 & 0.022 & 0.24 \\
\hline México & $\begin{array}{l}\text { Chicos }(n=204) \\
\text { Chicas }(n=185)\end{array}$ & $\begin{array}{l}5.50 \\
4.69\end{array}$ & $\begin{array}{l}1.43 \\
1.79\end{array}$ & 4.92 & 0.000 & 0.49 & $\begin{array}{l}6.06 \\
5.68\end{array}$ & $\begin{array}{l}1.08 \\
1.30\end{array}$ & 3.06 & 0.002 & 0.31 & $\begin{array}{l}5.50 \\
5.10\end{array}$ & $\begin{array}{l}1.28 \\
1.43\end{array}$ & 2.88 & 0.004 & 0.29 & $\begin{array}{l}5.30 \\
5.03\end{array}$ & $\begin{array}{l}1.35 \\
1.42\end{array}$ & 1.89 & 0.049 & 0.19 \\
\hline \multirow[t]{2}{*}{ Spain } & $\begin{array}{l}\text { Chicos }(n=528) \\
\text { Chicas }(n=541)\end{array}$ & $\begin{array}{l}4.68 \\
3.62\end{array}$ & $\begin{array}{l}1.68 \\
1.62\end{array}$ & 10.42 & 0.000 & 0.64 & $\begin{array}{l}5.64 \\
5.24\end{array}$ & $\begin{array}{l}1.37 \\
1.36 \\
\end{array}$ & 4.82 & 0.000 & 0.29 & $\begin{array}{l}4.80 \\
4.38\end{array}$ & $\begin{array}{l}1.52 \\
1.51 \\
\end{array}$ & 4.54 & 0.000 & 0.27 & $\begin{array}{l}4.79 \\
4.58\end{array}$ & $\begin{array}{l}1.46 \\
1.39\end{array}$ & 2.41 & 0.016 & 0.14 \\
\hline & \multicolumn{21}{|c|}{ Leisure-time sports and physical activity behaviors } \\
\hline Costa Rica & $\begin{array}{c}\text { Sedentary }(n=36) \\
\text { Active }(n=280)\end{array}$ & $\begin{array}{l}3.61 \\
4.78\end{array}$ & $\begin{array}{l}1.90 \\
1.78\end{array}$ & -3.70 & 0.000 & -0.63 & $\begin{array}{l}5.07 \\
5.37\end{array}$ & $\begin{array}{l}1.68 \\
1.47\end{array}$ & -1.32 & 0.048 & -0.19 & $\begin{array}{l}4.33 \\
4.98\end{array}$ & $\begin{array}{l}1.83 \\
1.54\end{array}$ & -2.34 & 0.020 & -0.38 & $\begin{array}{l}4.25 \\
4.95\end{array}$ & $\begin{array}{l}1.76 \\
1.48\end{array}$ & -2.63 & 0.009 & -0.43 \\
\hline México & $\begin{array}{c}\text { Sedentary }(n=252) \\
\text { Active }(n=124)\end{array}$ & $\begin{array}{l}4.97 \\
5.39\end{array}$ & $\begin{array}{l}1.73 \\
1.50\end{array}$ & -2.31 & 0.021 & -0.25 & $\begin{array}{l}5.80 \\
6.03 \\
\end{array}$ & $\begin{array}{l}1.24 \\
1.14 \\
\end{array}$ & -1.74 & 0.043 & -0.19 & $\begin{array}{l}5.15 \\
5.55\end{array}$ & $\begin{array}{l}1.38 \\
1.32 \\
\end{array}$ & -2.67 & 0.008 & -0.29 & $\begin{array}{l}5.08 \\
5.33\end{array}$ & $\begin{array}{l}1.40 \\
1.38\end{array}$ & -1.64 & 0.042 & -0.17 \\
\hline Spain & $\begin{array}{c}\text { Sedentary }(n=245) \\
\text { Active }(n=662)\end{array}$ & $\begin{array}{l}3.77 \\
4.23\end{array}$ & $\begin{array}{l}1.66 \\
1.74\end{array}$ & -3.55 & 0.000 & -0.27 & $\begin{array}{l}5.15 \\
5.53\end{array}$ & $\begin{array}{l}1.42 \\
1.36\end{array}$ & -3.64 & 0.000 & -0.27 & $\begin{array}{l}4.36 \\
4.66\end{array}$ & $\begin{array}{l}1.46 \\
1.55\end{array}$ & -2.59 & 0.010 & -0.19 & $\begin{array}{l}4.50 \\
4.77\end{array}$ & $\begin{array}{l}1.37 \\
1.43\end{array}$ & -2.50 & 0.013 & -0.19 \\
\hline & \multicolumn{21}{|c|}{ Leisure-time sports and physical activity } \\
\hline Costa Rica & $\begin{array}{c}\text { Low level of physical } \\
\text { activity }(n=234) \\
\text { High level of physical } \\
\text { activity }(n=78)\end{array}$ & 4.39 & 1.83 & -4.56 & 0.000 & -0.61 & 5.18 & 1.52 & -3.33 & 0.001 & -0.45 & 4.74 & 1.64 & -3.47 & 0.001 & -0.48 & $\begin{array}{l}4.75 \\
5.26\end{array}$ & $\begin{array}{l}1.55 \\
1.40\end{array}$ & -2.51 & 0.012 & -0.34 \\
\hline México & $\begin{array}{c}\text { Low level of physical } \\
\text { activity }(n=335) \\
\text { High level of physical } \\
\text { activity }(n=41)\end{array}$ & 5.74 & 1.71 & -2.60 & 0.009 & -0.48 & 6.05 & 1.23 & -0.98 & 0.323 & -0.17 & 5.21 & 1.38 & -3.29 & 0.001 & -0.59 & 5.50 & $\begin{array}{l}1.41 \\
1.25\end{array}$ & -1.78 & 0.080 & -0.28 \\
\hline Spain & $\begin{array}{l}\text { Low level of physical } \\
\text { activity }(n=597) \\
\text { High level of physical } \\
\text { activity }(n=307)\end{array}$ & 4.36 & 1.76 & -3.16 & 0.002 & -0.22 & 5.37 & 1.38 & -1.81 & 0.047 & -0.12 & 4.49 & 1.48 & -2.28 & 0.023 & -0.16 & 4.68 & 1.37 & -0.50 & 0.617 & -0.03 \\
\hline & & & & & & & & & Stag & ges of $\mathrm{cl}$ & lange & & & & & & & & & & \\
\hline Costa Rica & $\begin{array}{l}\text { Inactive Stages } \\
\text { Active Stages }\end{array}$ & $\begin{array}{l}4.33 \\
4.80\end{array}$ & $\begin{array}{l}2.09 \\
1.72\end{array}$ & -1.88 & 0.049 & -0.24 & $\begin{array}{l}5.25 \\
5.40\end{array}$ & $\begin{array}{l}1.67 \\
1.46\end{array}$ & -0.69 & 0.489 & -0.09 & $\begin{array}{l}4.68 \\
5.02\end{array}$ & $\begin{array}{l}1.75 \\
1.55\end{array}$ & -1.56 & 0.048 & -0.20 & $\begin{array}{l}4.75 \\
4.89\end{array}$ & $\begin{array}{l}1.70 \\
1.51\end{array}$ & -0.68 & 0.491 & -0.08 \\
\hline México & $\begin{array}{l}\text { Inactive Stages } \\
\text { Active Stages }\end{array}$ & $\begin{array}{l}4.99 \\
5.35\end{array}$ & $\begin{array}{l}1.73 \\
1.51\end{array}$ & -1.93 & 0.043 & -0.22 & $\begin{array}{l}5.80 \\
6.04 \\
\end{array}$ & $\begin{array}{l}1.23 \\
1.15 \\
\end{array}$ & -1.74 & 0.041 & -0.20 & $\begin{array}{l}5.16 \\
5.54\end{array}$ & $\begin{array}{l}1.37 \\
1.34 \\
\end{array}$ & -2.50 & 0.013 & -0.28 & $\begin{array}{l}5.08 \\
5.34\end{array}$ & $\begin{array}{l}1.40 \\
1.38\end{array}$ & -1.64 & 0.102 & -0.18 \\
\hline Spain & $\begin{array}{c}\text { Inactive Stages } \\
\text { Active Stages }\end{array}$ & $\begin{array}{l}3.78 \\
4.28\end{array}$ & $\begin{array}{l}1.66 \\
1.75\end{array}$ & -4.17 & 0.000 & -0.29 & $\begin{array}{l}5.24 \\
5.54\end{array}$ & $\begin{array}{l}1.40 \\
1.38\end{array}$ & -3.14 & 0.002 & -0.21 & $\begin{array}{l}4.47 \\
4.63\end{array}$ & $\begin{array}{l}1.46 \\
1.57\end{array}$ & -1.52 & 0.049 & -0.10 & $\begin{array}{l}4.62 \\
4.73\end{array}$ & $\begin{array}{l}1.41 \\
1.42\end{array}$ & -1.09 & 0.272 & -0.07 \\
\hline
\end{tabular}




\section{Discussion}

This study sought to discover the relationship between levels of leisure-time physical activity and stages of change and goal orientations in three different countries. A further aim was to see if the results were common to the three countries studied according to the sample analyzed.

When examining the known $2 \times 2$ in the body of literature [30-36], high school aged students seem less studied than younger ( $<14$ years of age) and older ( $>20$ years of age) students. Certainly, the present study is unique with examining three sets of high school students from different countries. In the case of physical activity, it is already known from authors such as Ramírez et al. [37] that it improves physical and psychologist factors of students. Furthermore, this study points out that basic cognitive processes such as attention, inhibitory control, and working memory, information processing speed in children who systematically take part in physical activity are better than in sedentary children. This indicates that devoting substantial time to physical activity can result in benefits in students' academic performance. This is even more interesting if this habit is related to students' social goals.

The descriptive analysis reveals that the most active students are in Costa Rica and that there is a high level of physical inactivity rate in Mexico and Spain. In spite of this, the National Survey on Cardiovascular Risk Factor in Costa Rica reported that $50.1 \%$ of Costa Ricans show high levels of sedentary lifestyle Encuesta Nacional sobre Factores de Riesgo Cardiovascular, CCSS [38]. Along the same lines, The Global School-Based Student Health Survey (GSHS) [39] revealed that only $27.4 \%$ of the population between 13 and 15 years of age are physically active and comply with the recommendation of doing at least $60 \mathrm{~min}$ of physical activity a day. Also, less than fifty percent of this adolescent population $(43 \%)$ walks or cycles to school and $44 \%$ spends 3 or more hours sitting down outside school hours, apart from doing homework, which means that their recreational activities are most likely sedentary in nature (GSHS, WHO). Regarding México, García-Pacheco and Hernández-Pozo [40] state that Mexican students have low levels of physical activity and that levels decrease with age, but the most alarming issue is the high dropout rate [41]. Moreover, recent figures [42] show that Mexico has the second highest rate of obesity in the world; $26 \%$ of children and $31 \%$ of adolescents suffer from this condition. This is clearly indicated in line with the results in this study in relation to physical activity level, where Mexico showed the lowest rates (12\%). But these low rates are seen not only in Mexico, but in the three countries studied, as shown by a series of papers [43] and by the present study.

In relation to the stages of change, students from Costa Rica and Spain are mostly within the active stages of change, whereas in Mexico, two-thirds of the population is within the inactive stages of change. Furthermore, the National Survey on Health and Nutrition (Encuesta Nacional de Salud y Nutrición) [44], concluded that Mexican adolescents between 10 and 19 years of age are $35.2 \%$ active, $24.4 \%$ are moderately active, and $40.4 \%$ are inactive, while $70 \%$ of school-aged children do no physical activity, and according to our study have no intention to change. This data thus strengthens the results found in this research and justifies the high inactivity and dropout rates.

The highest mean scores here were found in the mastery-approach subscale and the lowest in the performance-approach dimension. These results are similar in adolescents from the three countries studied so it is safe to state that this is a general trend and that it is in line with Cecchini et al., Cervelló et al., Méndez-Giménez et al., and Ruiz and Casado [4,44-47]. Furthermore, it is worth noting that the highest values in the mastery-approach correspond to the Mexican sample, whereas Spanish adolescents had the lowest rates in mastery-performance. These results can probably be accounted for by cultural differences.

In terms of gender, there are clear significant differences across the three countries, where boys always show higher mean values than girls. Lochbaum et al. [30] also found the same results but with university students, this leads us to think that these tendencies can be found through the years. However, not all the studies are in line with these results. Cecchini et al. [44], for instance, found that girls scored higher in task avoidance goals perhaps due to their perception of competition. Méndez-Giménez et al. [4], for their part, found that girls scored higher in mastery and higher rates of physical activity than boys. However, the majority of studies agree that boys show higher rates of 
physical activity [3]. Therefore, data contradicting this should be taken with caution and checked out in future research.

Another shared trend in the countries analyzed are the significant differences both in the performance approach and avoidance with the level of physical activity pattern, in which the highest values are seen in students with a high level of physical activity. This is a shared and understandable situation as these students are likely to be looking to obtain results and compete (typical performance pattern), hence their high level of physical activity.

In the case of the mastery-approach, it is related to more positive consequences [46], such as motivation, intention to practice sports, and effort, autonomy, and competition [4]. If we observe the results obtained in this research, this goal presents significant differences between Costa Rica and Spain and thus it can be regarded as a general tendency in all three countries. However, the fact that it is not related to Mexico can explain the high dropout and the lack of physical activity in view of the positive consequences of this goal. Thus, authors such as Wang et al. [5] and Méndez-Giménez et al. [4] showed that students with high achievement goals (high mastery-approach values) showed high levels of self-determined motivation, relationships with the others, fun, effort, and physical activity practice and low levels of boredom and amotivation.

Also worth noting as a shared tendency, is the relationship between mastery-avoidance and stages of change; no statistical significant differences were found in any of the three countries. In relation to physical education, when it comes to promoting positive behaviors in class, studies show that mastery-avoidance goals seem to be more suitable than performance-avoidance goals but less suitable than the mastery-approach [10,47-49]. However, the general trend in the three countries shows that there is no relationship with students' stages of change.

Finally, a common line was revealed across all three countries: the active stage of change variable had a significant relationship with the performance-approach, mastery-approach, and performance-avoidance with median values higher to those of inactive stages. That is, action stages (in which students have already made specific lifestyle changes over the past six months) and maintenance stages (when students make efforts to prevent relapses and has been making changes for 6 months), had a relationship with performance and the mastery-approach. Furthermore, this relationship is observed both with the performance-approach and mastery-approach; similarly, Wang et al. [5] noted that profiles combining high achievement goals and high mastery goals can present self-determined motivation in students and high levels of competition perception, good relationships with the others, fun, effort, physical activity practice, and low levels of boredom and amotivation, which would explain the relationship with these active stages. If we go back in time, Hardy et al. [50] already revealed that subjects with high task and ego orientation showed a pattern typical of elite athletes, that is, active people.

In the case of avoidance, as seen in Elliot [51] in relation to physical activity, these goals tend to be associated with negative behaviors in students. However, this is not necessarily the case and Wang et al. [5] is a clear example of this as this study shows that when avoidance goals are combined with approach goals they can generate an adaptative motivational pattern. Furthermore, Méndez-Giménez et al. [4] also obtained a high goals profile which was the most adaptative profile. If we observe the results of this research, students are likely to be in the same situation as the cited work and the combination of avoidance (makes a reference that the subject tries not to show its incompetence) and approach goals (involve reaching or maintaining desired outcomes) is probably the most suitable in terms of physical activity and active stages of change.

As for stages of change, adolescent students are in the action and maintenance stages, with $88 \%$ in Hausenblas et al. [52], 58.7\% in De Bourdeaudhuij [53], and 69.8\% in Montil et al. [54]. That is, the majority of students are in active stages, which is also related to the fact that most physical education students are in the mastery-approach stage, a goal mainly related to motivation for physical activity. 


\section{Conclusions}

Finally, it is worth highlighting that adolescence is a key period for students to acquire and consolidate physical activity habits or otherwise abandon them [55]. Furthermore, teachers are regarded as models that guide and promote these positive habits [56] through the creation of a class environment [57] and a climate which motivates students to partake in sports and physical activity in and out of school [58]. This research clearly shows the relationship between people who partake, or not, in leisure-time physical activity, the stage of change in which they are situated, and its potential relationship with achievement goals, taking the benefits that certain goals have on students as a reference point. Therefore, the data in this study are highly relevant for students, teachers, trainers, and even sports' institutions.

Author Contributions: F.R.-J. and A.B.-E. conceived the hypothesis of this study. R.B., M.E.G.-M., and M.d.M.O.-C. participated in data collection. F.R.-J. and A.B.-E. analyzed the data. All authors contributed to data interpretation of statistical analysis. R.B., A.B.-E., and F.R.-J. wrote the paper with significant input from A.B.-E. All authors read and approved the final manuscript.

Conflicts of Interest: The authors declare no conflicts of interest.

\section{References}

1. Conesa, M.D.; Juan, F.R. Clima motivacional en Educaicón Física y actividad físico-deportiva en el tiempo libre en alumnado de España, Costa Rica y México. Retos 2016, 29, 195-200.

2. Cecchini, J.A.; González, C.; Méndez-Giménez, A.; Fernández-Río, J. Achievement goals, social goals, and motivational regulations in physical education settings. Psicothema 2011, 23, 55-57.

3. Granero-Gallegos, A.; Baena-Extremera, A.; Pérez-Quero, F.J.; Ortiz-Camacho, M.M.; Bracho-Amador, C. Analysis of motivational profiles of satisfaction and importance of physical education in high school adolescents. J. Sports Sci. Med. 2012, 11, 614-623. [PubMed]

4. Méndez-Giménez, A.; Fernández-Río, J.; Cecchini, J.A.; González, C. Perfiles motivacionales y sus consecuencias en educación física. Un estudio complementario de metas de logro $2 \times 2$ y autodeterminación. Revista de Psicología del Deporte 2013, 22, 29-38.

5. Wang, J.; Biddle, S.; Elliot, A.J. The $2 \times 2$ achievement goal framework in a physical education context. Psychol. Sport Exerc. 2007, 8, 147-168. [CrossRef]

6. Standage, M.; Duda, J.L.; Ntoumanis, N. Predicting motivational regulations in PE: The interplay between dispositional goal orientations, motivational climate and perceived competence. J. Sport Sci. 2003, 21, 631-647. [CrossRef] [PubMed]

7. Deci, E.L.; Ryan, R.M. The "what" and "why" of goal pursuits: Human needs and the self-determination of behaviour. Psychol. Inq. 2000, 11, 227-268. [CrossRef]

8. Duda, J.L. Achievement goal research in sport: Pushing the boundaries and clarifying some misunderstandings. In Advances in Motivation in Sport and Exercise; Roberts, G.C., Ed.; Human Kinetics: Champaign, IL, USA, 2001; pp. 129-182.

9. Ames, C. Achievement goals, motivational climate, and motivational processes. In Motivation in Sport and Exercise; Roberts, G.C., Ed.; Human Kinetics: Champaign, IL, USA, 1992.

10. Nicholls, J.G. The Competitive Ethos and Democratic Education; Harvard University Press: Cambridge, MA, USA, 1989.

11. Cury, F.; Elliot, A.J.; Da Fonseca, D.; Moller, A. The socialcognitive model of achievement motivation and the $2 \times 2$ achievement goal framework. J. Personal. Soc. Psychol. 2006, 90, 666-679. [CrossRef] [PubMed]

12. Elliot, A.J.; McGregor, H.A. A $2 \times 2$ achievement goal framework. J. Personal. Soc. Psychol. 2001, 80, 501-519. [CrossRef]

13. González-Cutre, D.; Sicilia, A.; Moreno, J.A. Modelo cognitivo-social de la motivación de logro en EF. Psicothema 2008, 20, 642-651.

14. Marcus, B.H.; Forsyth, L.H. Physical Activity Intervention Series: Motivating People to Be Physically Active; Human Kinetics: Champaign, IL, USA, 2003; pp. 16-17.

15. Prochaska, J.O.; DiClemente, C.C.; Norcross, J.C. In Search of How People Change: Applications to Addictive Behaviors. Am. Psychol. 1992, 47, 1102-1114. [CrossRef] [PubMed] 
16. Ardoy, D.N.; Fernández-Rodríguez, J.M.; Chillón, P.; Artero, E.; España-Romero, V.; Jiménez-Pavón, D.; Ruiz, J.; Guiraldo-Escámez, C.; Castillo, M.; Ortega, F. Educando para mejorar el estado de forma física, estudio EDUFIT: Antecedentes, diseño, metodología y análisis del abandono/adhesión al estudio. Revista Española de Salud Publica 2010, 84, 151-168. [CrossRef] [PubMed]

17. Nuviala, A.; Gómez-López, M.; Pérez, J.A.; Nueviala, R. Lifestyle and Physical Education. J. Hum. Kinet. 2011, 27, 149-162. [CrossRef]

18. Piéron, M.; Ruiz-Juan, F.; García, M.E.; Díez, A. Análise da prática de atividades físico-esportivas em alunos de ESO e ESPO das províncias de Almería, Granada e Murcia por um índice composto de participação. Fithnes Perform. J. 2008, 7, 52-58. [CrossRef]

19. Ruiz-Juan, F.; García, E.; García, M.E.; Bush, P.L. Role of individual and school factors in physical activity patterns of secondary-level Spanish students. J. Sch. Health 2010, 80, 88-95. [CrossRef] [PubMed]

20. Telama, R.; Yang, X.; Viikari, J.; Välimäki, I.; Wanne, O.; Raitakari, O. Physical Activity from Childhood to Adulthood. A 21-Year Tracking Study. Am. J. Prev. Med. 2005, 28, 267-273. [CrossRef] [PubMed]

21. Marcus, B.H.; Rakowski, W.; Rossi, J.S. Assessing motivational readiness and decision-making for exercise. Health Psychol. 1992, 11, 257-261. [CrossRef] [PubMed]

22. Bucksch, J.; Finne, E.; Kolip, P. The transtheoretical model in the context of physical activity in a school-based sample of German adolescents. Eur. J. Sport Sci. 2008, 8, 403-412. [CrossRef]

23. Cardinal, B.J.; Jong-Young, L.; Young-Ho, K.; Lee, H.; Kin-Kit, L.; Si, Q. Behavioral, Demographic, Psychosocial, and Sociocultural Concomitants of Stage of Change for Physical Activity Behavior in a Mixed-Culture Sample. Am. J. Health Promot. 2009, 23, 274-278. [CrossRef] [PubMed]

24. Ciccomascolo, L.; Riebe, D. Stages of change and physical education assessment. (Teaching Tips). J. Phys. Educ. Recreat. Dance 2008, 79, 13-15.

25. Moreno, J.A.; González-Cutre, D.; Sicilia, A. Metas de logro $2 \times 2$ en estudiantes españoles de Educación Física. Revista de Educación 2008, 347, 299-317.

26. Carretero-Dios, H.; Pérez, C. Normas para el desarrollo y revisión de estudios instrumentales. Int. J. Clin. Health Psychol. 2005, 5, 521-551.

27. Bollen, K.; Long, J. Testing Structural Equation Models; Sage: Newbury Park, CA, USA, 1994.

28. Kline, R. Principles and Practice of Structural Equation Modeling; Guilford: New York, NY, USA, 1998.

29. Hair, J.F.; Black, W.C.; Babin, B.J.; Anderson, R.E.; Tatham, R.L. Multivariate Data Analysis, 7th ed.; Pearson Prentice Hall: New York, NY, USA, 2009.

30. Lochbaum, M.; Podlog, L.; Litchfield, K.; Surles, J.; Hilliard, S. Stage of physical activity and approach-avoidance achievement goals in university students. Psychol. Sport Exerc. 2013, 14, 161-168. [CrossRef]

31. Wilkins, N.J.; Kuperminc, G. Why try? Achievement motivation and perceived academic climate among Latino youth. J. Early Adolesc. 2010, 30, 246-276. [CrossRef]

32. Agbuga, B.; Xiang, P. Achievement goals and their relations to self-reported persistence/effort in secondary physical education: A trichotomous achievement goal framework. J. Teach. Phys. Educ. 2008, 27, 179-191. [CrossRef]

33. Agbuga, B.; Xiang, P.; McBride, R. Achievement goals and their relations to children's disruptive behaviors in an after-school physical activity program. J. Teach. Phys. Educ. 2010, 29, 278-294. [CrossRef]

34. Bortoli, L.; Bertollo, M.; Vitali, F.; Filho, E.; Robazza, C. The Effects of Motivational Climate Interventions on Psychobiosocial States in High School Physical Education. Res. Q. Exerc. Sport 2015, 86, 196-204. [CrossRef] [PubMed]

35. Hastie, P.; Sinelnikov, O.; Wallhead, T.; Layne, T. Perceived and actual motivational climate of a mastery-involving sport education season. Eur. Phys. Educ. Rev. 2014, 20, 215-228. [CrossRef]

36. Warburton, V.; Spray, C. Antecedents of approach-avoidance achievement goal adoption: An analysis of two physical education activities. Eur. Phys. Educ. Rev. 2013, 19, 215-231. [CrossRef]

37. Ramírez, W.; Vinaccia, S.; Suárez, G. El impacto de la actividad física y el deporte sobre la salud, la cognición, la socialización y el rendimiento académico: Una revisión teórica. Revista de Estudios Sociales 2004, 18, 67-75.

38. Encuesta Nacional sobre Factores de Riesgo Cardiovascular. Caja Costarricense del Seguro Social (CCSS). 2010.

39. Ministerio de Salud. Encuesta Global de Salud Escolar. Global School-based Student Health Survey (GSHS), San José, Costa Rica. 2010. Available online: http:/ / www.icd.go.cr/portalicd/images/docs/uid/informes/ Situacion_Nacional_2009.pdf (accessed on 25 January 2015). 
40. García-Pacheco, A.F.; Hernández-Pozo, M.R. Programas de intervención para mejorar los niveles de actividad física en niños de nivel educativo básico e intermedio: UNA revisión sistemática. J. Behav. Health Soc. Issues 2011, 3, 25-47. [CrossRef]

41. Zamarripa, J.I.; Ruiz-Juan, F.; López, J.M.; Baños, R. Actividad e inactividad física durante el tiempo libre en la población adulta de Monterrey (Nuevo León, México). Retos 2013, 24, 91-96.

42. Organización para la Cooperación y el Desarrollo Económico (OCDE). 2011. Informe PISA. Available online: http: / / www.pisa.oecd.org/ (accessed on 19 January 2015).

43. Instituto Nacional de Salud Pública. Encuesta Nacional de Salud y Nutrición; (ENSANUT): Cuernavaca, México, 2006; p. 382.

44. Cecchini, J.A.; González, C.; Méndez-Giménez, A.; Fernández-Río, J.; Contreras, O.; Romero, S. Metas sociales y de logro, persistencia-esfuerzo e intenciones de práctica deportiva en el alumnado de Educación Física. Psicothema 2008, 20, 260-265.

45. Cervelló, E.; Moreno, J.A.; Martínez, C.; Ferriz, R.; Moya, M. El papel del clima motivacional, la relación con los demás, y la orientación de metas en la predicción del flow disposicional en educación física. Revista de Psicología del Deporte 2011, 20, 165-178.

46. Ruiz, G.; Casado, R. Orientación motivacional en estudiantes de educación física pertenecientes al programa de cualigicación profesional inicial (P.C.P.I.) y su contraste con alumnos de la E.S.O. AGON Int. J. Sport Sci. 2012, 2, 17-24.

47. Moller, A.C.; Elliot, A.J. The $2 \times 2$ achievement goal framework: An overview of empirical research. In Focus on Educational Psychology; Mittel, E.A., Ed.; Nova Science Publishers, Inc.: New York, NY, USA, 2006.

48. Moreno, J.A.; Gonzales-Cutre, D.; Sicilia, A.; Spray, C.M. Motivation in the exercise setting: Integrating constructs from the approach-avoidance achievement goal framework and self-determination theory. Psychol. Sport Exerc. 2010, 11, 542-550. [CrossRef]

49. Nien, C.L.; Duda, J.L. Antecedents and consequences of approach and avoidance achievement goals: A test of gender invariance. Psychol. Sport Exerc. 2008, 9, 352-372. [CrossRef]

50. Hardy, L.; Jones, G.; Gould, D. Understanding Psychological Preparation for Sport: Theory and Practice of Elite Performers; John Wiley and Sons: Chichester, UK, 1996.

51. Elliot, A.J. Integrating the "classic" and "contemporary" approaches to achievement motivation. In Advances in Motivation and Achievement; Maehr, E.M., Printrich, P., Eds.; JAI Press: Greenwich, CT, USA, 1997; Volume 10, pp. 243-279.

52. Hausenblas, H.A.; Nigg, C.R.; Symons-Downs, D.; Fleming, D.; Connaughton, D. Perceptions of exercise stages, barriers self-efficacy, and decisional balance for middle-level school students. J. Early Adolesc. 2002, 22, 436-454. [CrossRef]

53. De Bourdeaudhuij, I. Applying the transtheroretical model for change in physical activity in young people. Revista Portuguesa de Ciências do Desporto 2003, 3, 16-17.

54. Montil, M.; Barriopedro, M.A.; Oliván, J. Actividad física y estados de cambio en población infantil: Un estudio sobre validez convergente. Apunts Educación Física y Deportes 2007, 4, 20-26.

55. Cervelló, E.; Escartí, A.; Guzmán, J.F. Youth sport dropout from the achievement goal theory. Psicothema 2007, 19, 65-71. [PubMed]

56. Moreno, J.A.; Zomeño, T.E.; Marín, L.M.; Ruiz-Pérez, L.M. Percepción de la utilidad e importancia de la EF según la motivación generada por el docente. Revista de Educación 2013, 362, 380-401.

57. Baena-Extremera, A.; Granero-Gallegos, A.; Sánchez-Fuentes, J.; Martínez-Molina, M. Apoyo a la autonomía en educación física: Antecedentes, diseño, metodología y análisis de la relación con la motivación en estudiantes adolescentes. Retos 2013, 24, 46-49.

58. Moreno, J.A.; Vera, J.A.; Cervelló, E. Evaluación participativa y responsabilidad en Educación Física. Revista de Educación 2006, 30, 731-754.

(C) 2018 by the authors. Licensee MDPI, Basel, Switzerland. This article is an open access article distributed under the terms and conditions of the Creative Commons Attribution (CC BY) license (http:/ / creativecommons.org/licenses/by/4.0/). 